\title{
円リングにおける自重大たわみ変形を利用した薄肉積層材料の 新ヤング率測定法（自重大変形積層円リング法）
}

\author{
大槻敦巳 ${ }^{* *}$, 蒋 驍 $* * *$
}

\section{An Innovative Large Deformation Method for Measuring Young's Modulus in a Thin Flexible Multi-layered Material (Own-weight Multi-layered Circular Ring Method)}

\begin{abstract}
Atsumi OHTSUKI and Gyo SHO
In application of thin flexible multi-layered materials, it is very important to evaluate mechanical properties of these materials in both analytical and technological interests. In this study, a new and convenient mechanical testing method (Own-weight Multi-layered Circular Ring Method) is developed for measuring Young's modulus of each layer in a flexible multi-layered material (thin plate, or rod/wire), especially, as a useful technique to overcome the difficulty in measuring Young' s modulus of a curled/ curved flexible multi-layered material. The method is based on a nonlinear theory that takes into account large deformation behaviors of flexible multi-layered materials. By just measuring a maximum horizontal displacement or a maximum vertical displacement in a flexible circular ring, Young's modulus of each layer can be easily obtained for various thin multi-layered materials (plate and rod/wire). As an example, measurements were carried out on a thin curled/curved two-layered wire consisting of a thin steel wire (a piano wire: SWP-B) and a thin plating layer (an electrodeposited nickel layer: Ni). The results elucidate that the innovative new method could be applied to measure Young's modulus of thin flexible multilayered materials. In the meantime, the new method "Own-weight Multi-layered Circular Ring Method" proposed in this paper is quite a promising method and can be applied widely to measure Young's modulus of every thin layer in a flexible multi-layered material formed by PVD, CVD, Coating, Paint, Cladding, Lamination and others besides electrodeposited thin layers.
\end{abstract}

Key Words: Material testing, Circular ring, Young's modulus, Own weight deformation, Large deformation, Thin material, Flexible materials, Multi-layered material

\section{1. 緒 言}

大きなたわみ変形を示す薄肉材料 (金属系の薄板／細線, 高分子材料など)がばね用部材あるいは機械構造用部材と して広く使用され，しかもばね性能の向上のために積層化 されて使われることも多い.ばねなどにおいては，防錆の みならず強度改善のため施されるめっき処理材などが代表 例である。こうした薄肉積層材料の強度設計においては, 積層を構成する各層の個々のヤング率(縦弾性係数)を知る ことが工業的に極めて重要であって, 積層材料全体を単一 体と見做して近似的，平均的なヤング率で充当するのは適 切でないといえる。また，構成薄肉積層材料のヤング率自 体も成形プロセスに起因しバルク材のそれとは異なること が多く, バルク材のヤング率をそのまま利用して積層時の ヤング率を推定するにはいささか懸念がある.したがって,

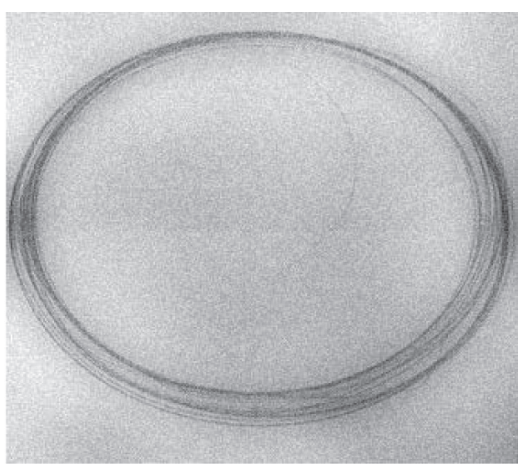

Fig. 1 General storage condition of thin materials (As an example, curled/curved wire with small diameter).

こういった積層材料の実測のヤング率が必要なのである が, これらの薄い, 細い積層材料は低剛性のため, 微小変 形を基礎とする従来の規格化された材料試験法(引張試験

原稿受付日 2017年12月7日

*日本ばね学会2017年度秋季講演会

** 名城大学 (Meijo University)

** 名城大学大学院 院生 (Meijo University, Graduate student) 
あるいは圧縮試験, 片持ちはり試験, 三点/四点曲げ試験 など)を用いてヤング率を求めるのは単体の薄肉材料でも 一般には困難であり, いわんや薄肉積層材料ではなおさら 極めて難しいといえる。線形理論に基づく従来の一般的な ヤング率測定法は測定材料規格に合致するような十分な厚 さ, 太さを有する剛性の大なる単体の弾性体のヤング率測 定が中心である。しかもそうした既存の測定理論の中にも 本論文で取り扱ったような円リングを利用した一般的測定 法は全く見かけない。すなわち，ここで取り上げた円リン グ法自体が極めて特筆すべき，ユニークなヤング率測定法 なのである，そこで，本論文ではこうした可撓性の高い薄 肉積層材料の構成各層のヤング率の測定方法として, 極め て画期的な「自重大変形積層円リング法」を開発した。すな わち, 薄い, 細いままの積層材料を円リング状(基本的に は多少真直性を損なった材料を円リングにすることを想定 しているが, 元々真っすぐでも, 最初から曲がっていても 大丈夫. )に形成したのち, その上端部の一点を支持すれば, 円リング自体の自重によって大たわみ変形が生じるはずで ある。開発した方法はこの大たわみ変形挙動の利用に着目 したヤング率測定法である. 円リング形成は弾性変形範囲 を予想しているが, もし, 円リング形成の際に薄肉積層材 料に塑性変形が生じたとしても，その後の変形計測には自 重弾性変形を利用するので, ヤング率測定に当たっては円 リング試料形成時の塑性変形について格別懸念する必要は ない. 特に, 本方法はFig.1に示すように, 薄い, 細い材 料のために，材料が何重にも太巻き／コイル状に巻かれて 保管されたため曲りクセのついた薄肉積層材料や何かの原 因で初期曲率(曲りといってもよい)を有することになった 薄肉積層材料などに対しては有効であり, 極めて斬新なヤ ング率測定法といえるものである.

なお，本測定法の有効性を確かめるために，大きな可撓 性を有する2層積層細線(ニッケルめっきされたピアノ細 線)について各層のヤング率測定実験を行った。ちなみに, 開発した自重大変形積層円リング法は, 特別な装置も要ら ず簡単な方法であり, カーボンファイバー, オプティカル ファイバー, 紙, 織布など測定の難しい非金属薄肉材料の 単体としてのヤング率測定にも適用できるほか, 薄肉積層 材料のめっき薄膜を始め, コーティング薄膜, ICチップ上

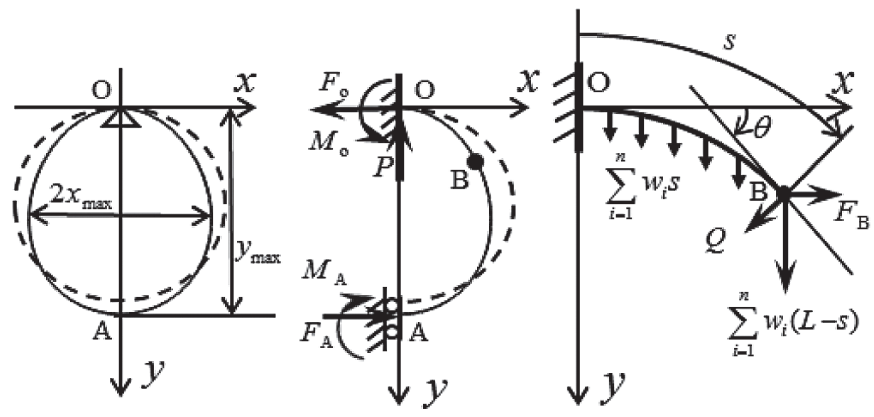

Fig. 2 Large deformations of a multi-layered circular ring subjected to own-weight.
の薄膜, 医用デバイス薄膜, MEMS用薄膜などのマイク ロマテリアルやPVD薄膜,, CVD薄膜, クラッド材, ラミネー 卜材などのヤング率測定にも応用し得る，極めて拡張性の 高い測定法である。

ところで, 薄肉材料のヤング率測定に関しては, 箔や薄 膜単体について既存方法を改良した引張試験によって測

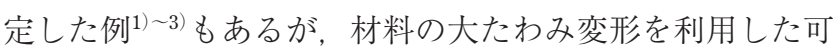
撓性材料のヤング率測定法についてはほとんどなく，薄 肉単層材料に関しては, 外荷重負荷方式による片持ちはり

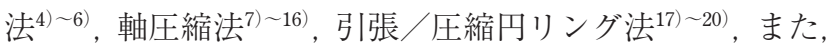
自重方式による片持ちはり法 ${ }^{21)}$ 22), 円リング法 ${ }^{23)}$ (25)など が提案されており, 一方, 薄肉積層材料については外荷重 負荷方式による片持ちはり法 ${ }^{26)}$ 28), 軸圧縮法 ${ }^{29)}$ (33), 引張 /圧縮円リング法 ${ }^{34)}$ ３6)，また，自重方式による片持ちは り法 ${ }^{37)}$ 39) など, 散見される程度である。

\section{2. ヤング率測定の基礎理論}

本解析における主な前提条件は下記の通りである。

(1) 理論の適用範囲は弾性領域の非線形大変形である.

(2) Euler-Bernoulliの仮定が成り立つものとし, 非線形理

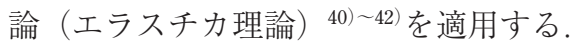

（3）せん断力の影響やポアソン効果などは考慮しない.

（4）積層材料は大変形に際して不伸長とする.

Fig.2に示すように，任意 $i$ 層の単位長さ当たりの自重を $w_{i}$ とする，上部の一端を支持された $n$ 層積層自重円リング (全周長さ $2 L$ )において, 固定端(座標原点)を $\mathrm{O}$, 水平方向 に距離 $x$, 垂直方向に距離 $y$ をり，任意点 $\mathrm{B}(x, y)$ までのた わみ曲線円弧長さを $s$, 点Bでのたわみ角を $\theta$ とする。

ここで,リング部材の任意 $i$ 層のヤング率を $E_{i}$, 断面二 次モーメントを $I_{i}$ とする。特に, Fig.3は2層薄板 $(n=2)$ の場 合の断面図を例示したもので， $z$ 軸から中立軸までの距離 をy, 中立軸から任意軸までの距離をyとする。
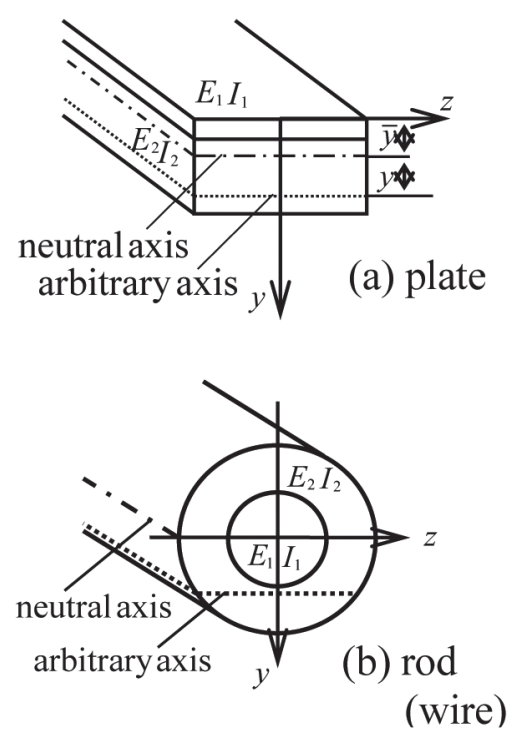

Fig. 3 Illustrations of cross-section (Example: two-layered material). 


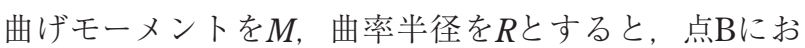
いて, $R, M, s, x, y, \theta$ の各量間には次式の関係が成り 立つ.

$$
\left.\begin{array}{l}
\frac{1}{R}=-\frac{d \theta}{d s}=\frac{M}{\sum_{i=1}^{n}\left(E_{i} I_{i}\right)}, \\
d x=d s \cdot \cos \theta, d y=d s \cdot \sin \theta
\end{array}\right\}
$$

なお, ここでは円リングはりの変形対称性を考慮して右半 分のみを解析することとする。

原点Oにおける水平力を $F_{0}$, 曲げモーメントを $M_{0}$, 任 意点に作用する垂直力を $F_{\mathrm{B}}$ とすれば，任意点 $\mathrm{B}(x, y)$ に作用 するせん断力 $Q$ のつり合いを表す次の式(2)

$$
Q=\sum_{i=1}^{n} w_{i}(L-s) \cos \theta-F_{\mathrm{B}} \sin \theta
$$

より，自重円リングの変形挙動を支配するたわみの基礎式 として次式 (3) が得られる.

$$
\sum_{i=1}^{n} E_{i} I_{i}\left(\frac{d^{2} \theta}{d s^{2}}\right)=-\sum_{i=1}^{n} w_{i}(L-s) \cos \theta+F_{\mathrm{B}} \sin \theta
$$

ここで，（4）式に示す無次元変数

$$
\begin{aligned}
& \xi=\frac{x}{L}, \eta=\frac{y}{L}, \zeta=\frac{s}{L}, \gamma=\sum_{i=1}^{n}\left(\frac{w_{i} L^{3}}{E_{i} I_{i}}\right) \\
& A=\frac{F_{\mathrm{B}} L^{2}}{\sum_{i=1}^{n}\left(E_{i} I_{i}\right)}
\end{aligned}
$$

を導入すると，次に示す関係式 (5)，（6）が得られる.

$$
\frac{d^{2} \theta}{d \zeta^{2}}=-\gamma(1-\zeta) \cos \theta+A \sin \theta
$$

$$
d \xi=d \zeta \cdot \cos \theta, d \eta=d \zeta \cdot \sin \theta
$$

なお, この無次元分布荷重 $\gamma$ は上端を支持された積層自重 はりの大たわみ変形を支配する重要なパラメータである。

ところで, 非線形微分方程式 (5)の解析解を得ることは 一般に難しく，ここではRKG(Runge-Kutta-Gill) 法を用い て数值解析することとする。なお， RKG法の適用に際し ては, 二階の非線形微分方程式(5)を 2 つの一階の非線形 微分方程式に変換する必要がある。

そこで，無次元曲げモーメント $\mu$ を導入すると

$$
\mu=\frac{M L}{\sum_{i=1}^{n}\left(E_{i} I_{i}\right)}
$$

たわみ角 $\theta$ と無次元曲げモーメント $\mu$ の関係より式 $(8)$, （9）が得られる.

$$
\begin{aligned}
& \frac{d \theta}{d \zeta}=\mu \ldots \ldots \ldots \ldots \ldots \ldots \ldots \ldots \ldots \ldots \ldots \ldots \ldots \ldots \\
& \frac{d \mu}{d \zeta}=-\gamma(1-\zeta) \cos \theta+A \sin \theta
\end{aligned}
$$

なお，境界条件は（10）式である.

$$
\begin{aligned}
& \left.\theta\right|_{\zeta=0}=\left.\xi\right|_{\zeta=0}=\left.\eta\right|_{\zeta=0}=0 \\
& \left.\theta\right|_{\zeta=\zeta^{*}}=\pi / 2 \\
& \left.\theta\right|_{\zeta=1}=\pi,\left.\xi\right|_{\zeta=1}=0
\end{aligned}
$$

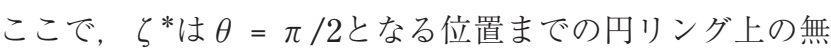
次元円弧長さである。

一方，適切な初期值を決定するためには，ここでは挟み 撃ち法(False Position Method)を用い，式(6)，（8)，（9） を連立微分方程式として数值解析を行った。すなわち，円 リングが真円の状態 $(\theta=\xi=\eta=0)$ から徐々に無次元分 布荷重 $\gamma$ を増加させつつ境界条件である式(10)を満たす $A$ および $\left.\mu\right|_{\zeta=0}$ を探索し, 最終的に, 無次元分布荷重 $\gamma に$ 対応する無次元最大水平距離 $\xi_{\text {max }}$ と無次元最大垂直距離 $\eta$ max 求めるのである.

以上が自重大たわみ変形を利用した積層円リング法によ る構成各層のヤング率測定の基礎理論であり，数值解析手 法である。したがって，自重積層円リングの各層ヤング 率 $E_{i}$ は，原理的には上述の解析理論に基づき，式(4)の無 次元水平距離 $\xi_{\text {max }}\left(=x_{\text {max }} / L\right)$ や無次元垂直距離 $\eta_{\text {max }}\left(=y_{\text {max }} /\right.$ $L)$, さらに無次元分布荷重 $\gamma$ などを利用して算出するこ とができるが，概して測定理論の取り扱いが安易とは言い 難い。そこで，ここでは各層のヤング率測定に供するため に便利な手法を開発した。すなわち,簡易方法として式(4) 第4式を変形した次式(11)を用いれば，所要の各層ヤング 率 $E_{i}$ を容易に求めることが可能となるのである.

$$
\sum_{i=1}^{n}\left(E_{i} I_{i}\right)=\frac{\sum_{i=1}^{n} w_{i} L^{3}}{\gamma}
$$

なお, 式（11）において各積層構成要素の曲げ剛性の総和 $\sum_{i=1}^{n}\left(E_{i} I_{i}\right)$ が重要で, そのために積層はり全体の中立軸位 置を知る必要がある。特に，層状断面が，中立軸に対し非 対称となる積層薄板はりの場合には必ず中立軸位置を算定 しなければならない。一方，対称断面となる積層細線の場 合には，積層材料中心が常に中立軸なのでその算定は不要 
となるのである.

積層薄板はりの場合, 任意構成要素 $i$ 層 $\left(\right.$ 厚さ $h_{i}$, 同一幅 $b$ ) の横断面が中立軸に関して持つ断面二次モーメント $I_{i}$ の一 般式は式(12)

$$
\begin{array}{r}
I_{i}=\frac{b h_{i}^{3}}{12}+b h_{i}\left(\bar{y}-\frac{h_{i}}{2}-\sum_{k=1}^{i} h_{k-1}\right)^{2} \quad \cdots \\
\left(\text { ただし }, h_{0}=0, \quad i \leq n\right)
\end{array}
$$

で表され, 中立軸の位置 $y$ は任意 $i$ 層の横断面 (断面積 $A_{i}$ )が $z$ 軸に関して持つ断面一次モーメントを

$\left(S_{i}\right)_{z}$ とすれば式(13)で表される.

$$
\bar{y}=\frac{\sum_{i=1}^{n} E_{i}\left(S_{i}\right)_{z}}{\sum_{i=1}^{n}\left(E_{i} A_{i}\right)}
$$

ここで, 断面一次モーメント $\left(S_{i}\right)_{z}$ の一般式は式 (14) で示 させる．

$$
\left(S_{i}\right)_{z}=\frac{b h_{i}^{2}}{2}+b h_{i}\left(\sum_{k=1}^{i} h_{k-1}\right)
$$

本論文に抢いては, 薄肉積層材料の各層ヤング率測定の 特別な例として, 積層細線の場合について論述することと する。

\section{3. 新ヤング率測定法の概略}

従来の一般的なヤング率測定法(微小変形線形理論に基 づく引張, 片持ち, 支点曲げ試験などに基づく方法) は得 られた実験デー夕を基に簡単な計算式を用いて直接にヤン グ率の算出が可能であるが，本論文のように非線形大たわ み理論に基づく測定法の場合には, 測定理論の数式取扱い が容易ではなく，またその数式処理法の煩頊もあって実験 データから計算式によって直接求めることは甚だ難しいと いえる, そこで, 本論文では, 非線形解析理論をもとに あらかじめ数值解析した結果を図表化した計算図表(ノモ グラフ)を作成して抄き，その計算図表を適宜に利用して ヤング率を求める簡便な方法を提案することとする。 なお, 実験的に収集する基礎データとしては，ここでは自重円リ ングの最大水平距離 $x_{\max }$ 掠よび最大垂直距離 $y_{\max }$ を想定した.

便利で有用な計算図表として, 無次元分布荷重 $\gamma$ と水 平距離 $x_{\text {max }}$ の関係 $\left(\gamma-x_{\max } / L\right)$ をFig.4に, また無次元分布荷 重 $\gamma$ と垂直距離 $y_{\max }$ の関係 $\left(\gamma-y_{\max } / L\right)$ をFig.5にそれぞれ示 す。こうした計算図表を有効に利用することによって円リ ングの大たわみ変形時に扔ける無次元分布荷重 $\gamma$ を知り得 れば，積層材料を構成する各任意 $i$ 層の所要のヤング率 $E_{i}$ は，式(4)第4式を変形した次式(11)を用いて容易に求める ことができる。

$$
\sum_{i=1}^{n}\left(E_{i} I_{i}\right)=\frac{\sum_{i=1}^{n} w_{i} L^{3}}{\gamma}
$$

そこで，こうした計算図表に基づく測定手法を利用す るための参考 (ガイダンス)として, ピアノ細線 (SWP-B) (第1層：直径 $d_{1}=0.9052 \mathrm{~mm}$, 自重 $w_{1}=6.1167 \times 10^{-2} \mathrm{~N} / \mathrm{m}$ ) にニッケル $(\mathrm{Ni})$ めっき (第 2 層 : 厚さ $t=0.0143 \mathrm{~mm}$, 自重 $\left.w_{2}=1.776 \times 10^{-2} \mathrm{~N} / \mathrm{m}\right)$ が施されたされた 2 層積層細線におけ る積層各層のヤング率算出のプロセスの一例を以下の 3.1 節, 3.2節に示す.

ところで，本測定手法による実験デー夕収集の際に注意 すべきことは, ヤング率未知の積層数に応じて, 複数回

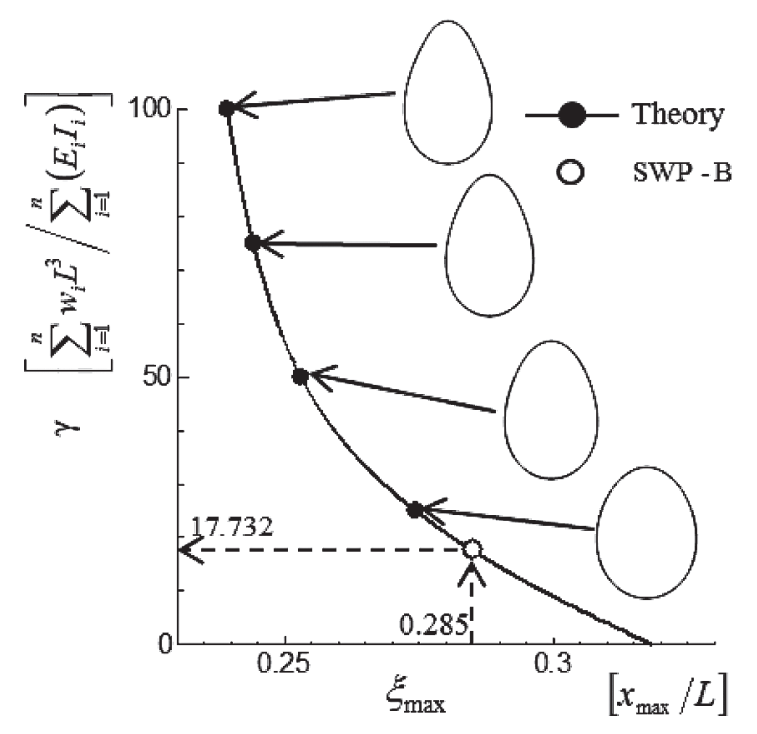

Fig. 4 Non-dimensional chart for finding the parameter $\gamma$ when the deflection $\xi_{\max }\left(x_{\max } / L\right)$ is given [Method 1].

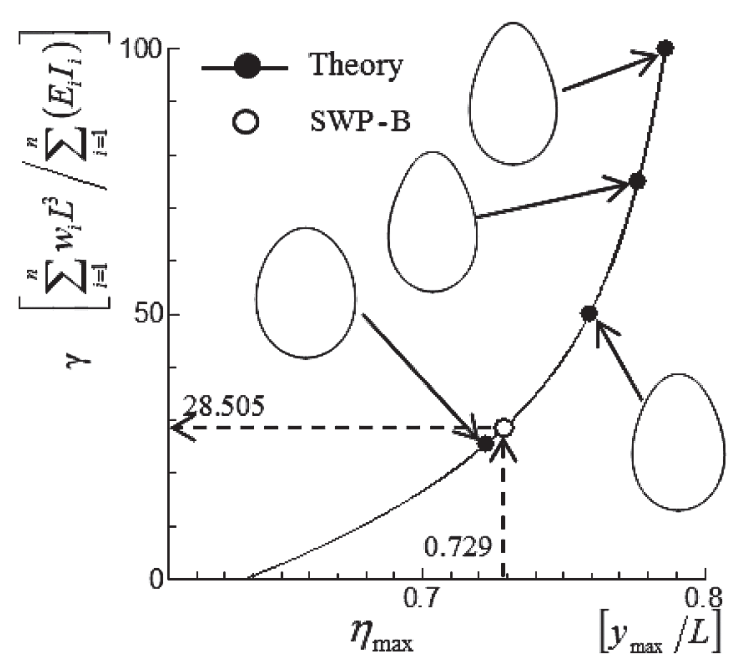

Fig. 5 Non-dimensional chart for finding the parameter $\gamma$ when the deflection $\eta_{\max }\left(y_{\max } / L\right)$ is given [Method 2]. 
(ステップ)の自重大たわみ変形実験を要することである. すなわち，3層ともヤング率が未知な積層はりの場合には3 層状態での実験 $\rightarrow 2$ 層状態での実験 $\rightarrow$ 単層状態での実験 という具合に積層数を減じつつ3ステップの自重大たわみ 変形実験が必要であって(注：3層であっても，2つの層た けヤング率が未知(残り 1層のヤング率既知)の場合には2 ステップの実験で良い), 各実験ステップで収集した水平, 垂直方向の変形デー夕を基に連立方程式を解いてようやく 各層のヤング率が確定するということである，なお，積層 する薄層の減じ方としては，適当な機械的方法，化学的方 法などから適宜選択するとよい。

なお，本測定法を利用すれば，単体での測定が極めて難 しい薄膜として代表的なコーティング薄膜, PVD, CVD 薄膜などの極薄肉材料のヤング率を簡単に求めることがで きる。すなわち、ヤング率があらかじめわかっている薄肉 母材にコーティングなどを施した2層積層材料(積層薄板, 積層細線) (補足：片面などにコーティングなどを施した薄 板などではコーティング材料に存在する内部応力 ${ }^{43) ~ 57) に ~}$ よってカール，湾曲するので，提案した本円リング法はそ の点で最適である)を作製したうえで，2層状態の自重大た わみ変形実験だけ (1ステップ)を実施することでコーティ ング薄膜などのヤング率を求めることができるのである。 ただ，その場合は母材(ヤング率既知）のみの単層自重大た わみ変形実験が省略できるだけであって，コーティング薄 膜などのヤング率を求めるために連立方程式を利用するこ とに変わりはない.

\section{1 最大水平距離 $\boldsymbol{x}_{\text {max }}$ を実験基礎データとしたヤング率 測定法［測定法1］}

総分布荷重 $\sum_{i=1}^{n} w_{i}$ を受ける積層円リングの自重大たわみ 変形において, 最大水平距離 $x_{\text {max }}(\theta=\pi / 2$ の位置) を計測 L， $\gamma-x_{\max } / L$ の関係を示す計算図表(Fig.4)を用いて無次 元分布荷重 $\gamma$ の值を読み取り，その $\gamma$ を式(11)に代入して 各層ヤング率 $\mathrm{E}_{i}$ を算出する方法である。なお，実験に際し てはヤング率未知の積層数に応じたデータ収集ステップが 必要であり，例として，2層の場合 (2層ともヤング率未知） は次の3.1.1項，3.1.2項のように2ステップの自重大たわみ 変形実験を要する.

\section{1 .1 第1ステップ（2層状態で計測データを収集）}

全円周長さ $2 L=2400 \mathrm{~mm}$ の 2 層めっきピアノ細線 (第 1 層 SWP-B : 直径 $d_{1}=0.9052[\mathrm{~mm}]$, 自重 $w_{1}=6.1167 \times 10^{-2}[\mathrm{~N} /$ $\mathrm{m}]$, 第2層 $\mathrm{Ni}$ : 厚さ $t=0.0143[\mathrm{~mm}]$, 自重 $w_{2}=1.776 \times 10^{-2}[\mathrm{~N} /$ $\mathrm{m}]$ )に抽，2層状態の自重大たわみ変形実験で，計測 データとして最大水平距離 $x_{\max }=342.0 \mathrm{~mm}$ 測定し, 無次 元水平距離 $\xi_{\text {max }}\left(=x_{\text {max }} / \mathrm{L}\right)$ に換算する. すなわち換算值の $\xi_{\text {max }}=0.2850$ に対して, 計算図表Fig.4 $\left(\gamma-x_{\text {max }} / L\right.$ 関係図 $)$ を 利用して無次元分布荷重 $\gamma=17.732$ を得たとき【注】, 合成 の曲げ剛性は式(11)より

$$
\begin{aligned}
& E_{1} I_{1}+E_{2} I_{2}=\frac{\left(w_{1}+w_{2}\right) L^{3}}{\gamma} \\
& =7.692 \times 10^{-3}\left[\mathrm{~N} / \mathrm{m}^{2}\right]
\end{aligned}
$$

\subsection{2 第2ステップ（単層状態で計測データを収集）}

次いで, ピアノ細線 (SWP-B)の単層状態(第2層のニッケ ル $(\mathrm{Ni})$ めっき薄層は層除去) で最大水平距離 $x_{\text {max }}=344.2 \mathrm{~mm}$ を測定し，その無次元換算值 $\xi_{\text {max }}=0.2868$ に対して，計算 図表Fig.4 $\left(\gamma-x_{\text {max }} / L\right.$ 関係図 $)$ を利用して無次元分布荷重 $\gamma=15.365$ (なお，ここ3.1.2項の手順については3.1.1項と同 様につき図示省略.ところで，Fig.4は第1ステップ，第2 テップで共用可の図である.) を得たとき【注】, 式(11)より 第1層ピアノ細線 $(\mathrm{SWP}-\mathrm{B})$ のヤング率 $E_{1}$ が次のように求ま る.

$$
\begin{aligned}
& E_{1}=\frac{w_{1} L^{3}}{\gamma I_{1}}=\frac{6.1167 \times 10^{-2} \times 1.2^{3}}{15.365 \times 3.296 \times 10^{-14}} \\
& =208.71[\mathrm{GPa}]
\end{aligned}
$$

一方，第2層のニッケル $(\mathrm{Ni})$ めっき薄層のヤング率 $E_{2}$ は, 算出した第1層ピアノ細線 $(\mathrm{SWP}-\mathrm{B})$ のヤング率 $E_{1}$ を基に, 式(12)と式(13)を連立させることによって最終的に確定す る。すなわち，次のように $E_{2}$ が算出される。

$$
\begin{aligned}
& E_{2}=\frac{\left\{\left(w_{1}+w_{2}\right) L^{3} / \gamma\right\}-E_{1} I_{1}}{I_{2}} \\
& =186.150[\mathrm{GPa}]
\end{aligned}
$$

\section{2 最大垂直距離 $y_{\text {max }}$ を実験基礎データとしたヤング率測 定法［測定法2］}

総分布荷重 $\sum_{i=1}^{n} w_{i}$ を受ける積層円リングの自重大たわみ 変形において最大垂直距離 $y_{\max }$ を計測し, $\gamma-y_{\max } / L$ の関 係を示す計算図表(Fig.5) を用いて無次元分布荷重 $\gamma$ の值 を読み取り，その $\gamma$ を式(11)に代入して各層ヤング率 $E_{i}$ を 計算する方法である。実験においては，3.1節と同様にヤ ング率未知の積層数に応じたデー夕収集ステップが必要で あり，例えば，2層の場合 (2層ともヤング率未知)には次の 3.2.1項，3.2.2項のように2ステップにわたる自重大たわみ 変形実験が必要である。

\subsection{1 第1ステップ（2層状態で計測データを収集）}

3.1.1項と同様の 2 層めっきピアノ細線について(ここでの 垂直距離測定実験3.2.1項の場合, 特別な理由はないが, 3.1 .1 項と異なり，使用した試料は全円周長さ $2 L=2800 \mathrm{~mm}$ の積 層円リングである)，2層状態の自重大たわみ変形実験にお いて, 計測データとして最大垂直距離 $y_{\text {max }}=1020.6 \mathrm{~mm}$ を測 定し, 無次元垂直距離 $\eta_{\max }\left(=y_{\max } / L\right)$ に換算する。すなわち 換算值の $\eta_{\max }=0.7290$ に対して，計算図表Fig.5 ( $\gamma-y_{\max } /$ L関係図) を利用して無次元分布荷重 $\gamma=28.505$ を得たとき 


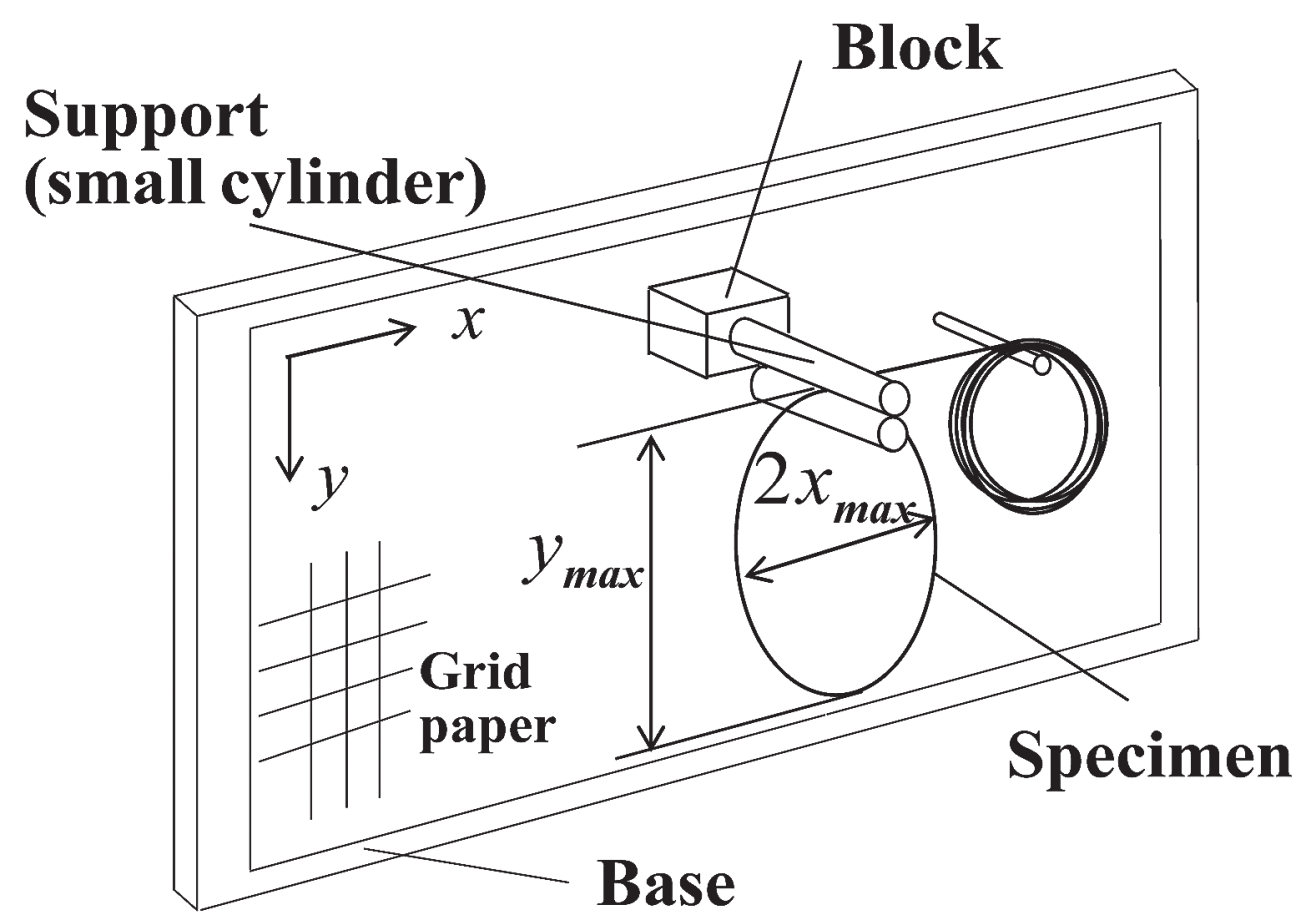

Fig. 6 Experimental set-up (as an example, a multi-layered wire specimen is shown).

【注】，合成の曲げ剛性は式(11)より

$$
\begin{aligned}
& E_{1} I_{1}+E_{2} I_{2}=\frac{\left(w_{1}+w_{2}\right) L^{3}}{\gamma} \\
& =7.598 \times 10^{-3}\left[\mathrm{~N} / \mathrm{m}^{2}\right]
\end{aligned}
$$

\subsection{2 第2ステップ（単層状態で計測データを収集）}

次いで, ピアノ細線 (SWP-B)の単層状態 (第2層のニッ ケル $(\mathrm{Ni})$ めっき薄層は層除去) で最大垂直距離 $y_{\max }=1011.5$ $\mathrm{mm}$ を測定し, その無次元換算值 $\eta$ max $=0.7225$ に対して, 計 算図表Fig.5 $\left(\gamma-y_{\max } / L\right.$ 関係図 $)$ を利用して無次元分布荷重 $\gamma=24.8804$ (なお, ここ3.2.2項の手順は3.2.1項と同様につ き図示省略. なお，Fig.5は第1ステップ，第2ステップで 共用可の図である.)を得たとき【注】, 式(11)より第1層ピ アノ細線 $(\mathrm{SWP}-\mathrm{B})$ のヤング率 $E_{1}$ は次のように算出される.

$$
\begin{aligned}
& E_{1}=\frac{w_{1} L^{3}}{\gamma I_{1}}=\frac{6.1167 \times 10^{-2} \times 1.4^{3}}{24.8804 \times 3.296 \times 10^{-14}} \\
& =204.67[\mathrm{GPa}]
\end{aligned}
$$

また, 第2層のニッケル $(\mathrm{Ni})$ めっき薄層のヤング率 $E_{2}$ は, 算出した第1層ピアノ細線 (SWP-B ) のヤング率 $E_{1}$ を基に, 式 (15), 式（16）の連立方程式を解くことによって最終 的に確定する。すなわち，次のように $E_{2}$ が計算される。

$$
\begin{aligned}
& E_{2}=\frac{\left\{\left(w_{1}+w_{2}\right) L^{3} / \gamma\right\}-E_{1} I_{1}}{I_{2}} \\
& =195.11[\mathrm{GPa}]
\end{aligned}
$$

\section{4. 薄肉積層材料の構成各層ヤング率の測定例}

新しく開発した薄肉積層材料の各層ヤング率測定法(自 重大変形積層円リング法)の有効性確認のため, 曲りク セのついた大きな可撓性を有する 2 層積層細線(ニッケル $(\mathrm{Ni})$ めっきの施されたピアノ細線 $(\mathrm{SWP}-\mathrm{B}))$ について自重 大たわみ変形状態のデー夕計測に基づき構成する積層各層 (Ni， SWP-B)のヤング率測定を行った。実験装置の概略 Fig.6に示す.

実験においては，上端を支持端とするために，ベースの 円筒部分と補助の円筒棒(いずれも $\phi 12 \mathrm{~mm}$ )に細線を挟み 保持した。また, 最大水平距離 $\left(2 x_{\max }\right)$ と最大垂直距離 $\left(y_{\max }\right)$ を測定するためには，利便性を考慮し装置基台に貼付した 方眼紙スケール $(1 \mathrm{~mm})$ を用いた。

なお，本測定例では積層を構成するいずれの層のヤング 率も不明な 2 層積層材料としているため, 各層のヤング率 を求めるに際しては，3章で示した測定手法の通り，2層状 態と単層状態の各ステップで自重大たわみ変形実験を実施 し, 所要の計測データである最大水平距離 $x_{\max }$ ならびに最 大垂直距離 $y_{\max }$ について収集を行った。

本測定実験においては, 積層円リングの全円周長さ $2 L=1200 \sim 3600 \mathrm{~mm}$ (すなわち, 半円長さ $L$ とては $L=600$ 〜 $1800 \mathrm{~mm}$ ) と変化(いわゆる円リングの大きさ( : 直径)を 変えること)させたときの自重大たわみ実験を行い, 各円 


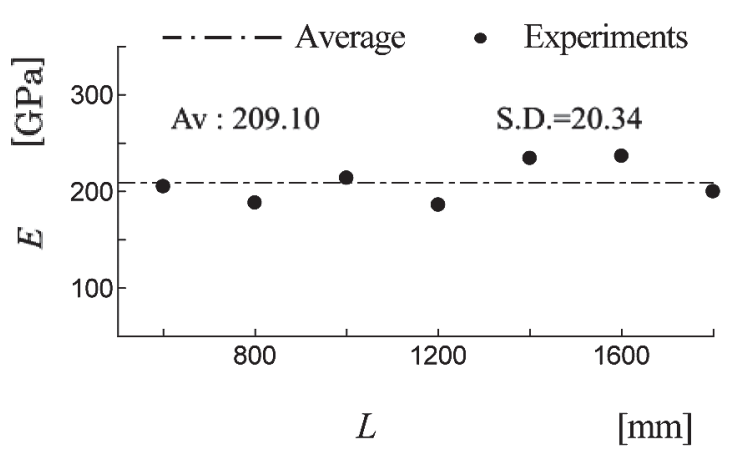

[Method 1]

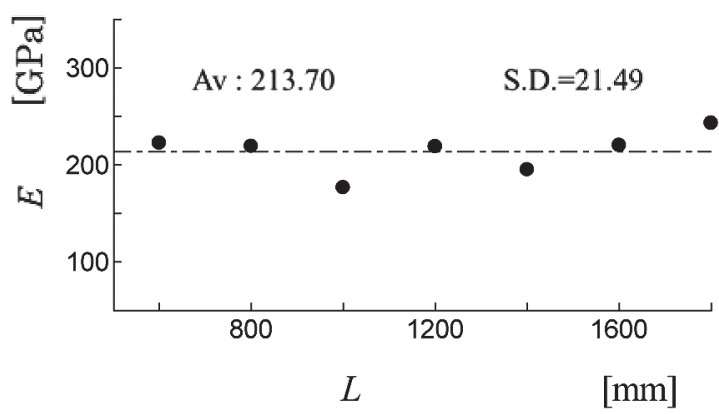

[Method 2]

Fig. 7 Comparison of Young's moduli for a piano wire (SWP-B: $E_{1}$ ) between the two measuring methods for various values of the length $L$. (Note: $E_{2}$ of $\mathrm{Ni}$ is known previously.).

周長さに関する構成各層のヤング率を算出した。

測定結果として，母材である第1層ピアノ細線(SWP-B, 直径 $0.9052 \mathrm{~mm}$ ) のヤング率についてFig.7に図示した。な お，図中のAv.は測定した各円周リング長さにわたって の相加平均, S.D.は各円周リング長さに関する標準偏差 (Standard Deviation)を表している. Fig.7から明らかなよ うに, 測定法 1 (最大水平距離 $x_{\text {max }}$ 計測法), 測定法 2 (最大 垂直距離 $y_{\max }$ 計測法) と採用する基礎デー夕 (最大水平距離 $x_{\text {max }}$ か最大垂直距離 $y_{\text {max }}$ ) が異なっているが, 両測定法とも 多少のばらつきがあるものの本実験の試験円リング長さ範 囲(半円長さ $L=600 \sim 1800 \mathrm{~mm}$ ) で測定された第1層ピアノ 細線 (SWP-B)のヤング率は試験円リング長さの長短に依 らずほぼ一定で，互いに良く一致していることがわかる. すなわち, リング円周長さ／線径比 $(: 2 L / d)$ が本実験の ように1200～3600倍程度の範囲では安定した十分な精度の 測定值が得られるといえる。

一方，第2層のニッケル $(\mathrm{Ni})$ めっき薄層 (厚さ $0.0143 \mathrm{~mm}$ ) のヤング率に関する測定結果をFig.8に示した。この場合 も測定法 1 (最大水平距離 $x_{\max }$ 計測法), 測定法 2 (最大垂直 距離 $y_{\text {max }}$ 計測法)の両測定法ともいくらかばらつきがある ものの試験円リング長さ範囲 (半円長さ $L=600 \sim 1800 \mathrm{~mm}$ ) の大たわみ変形実験では円リング長さに依らずほぼ一定の
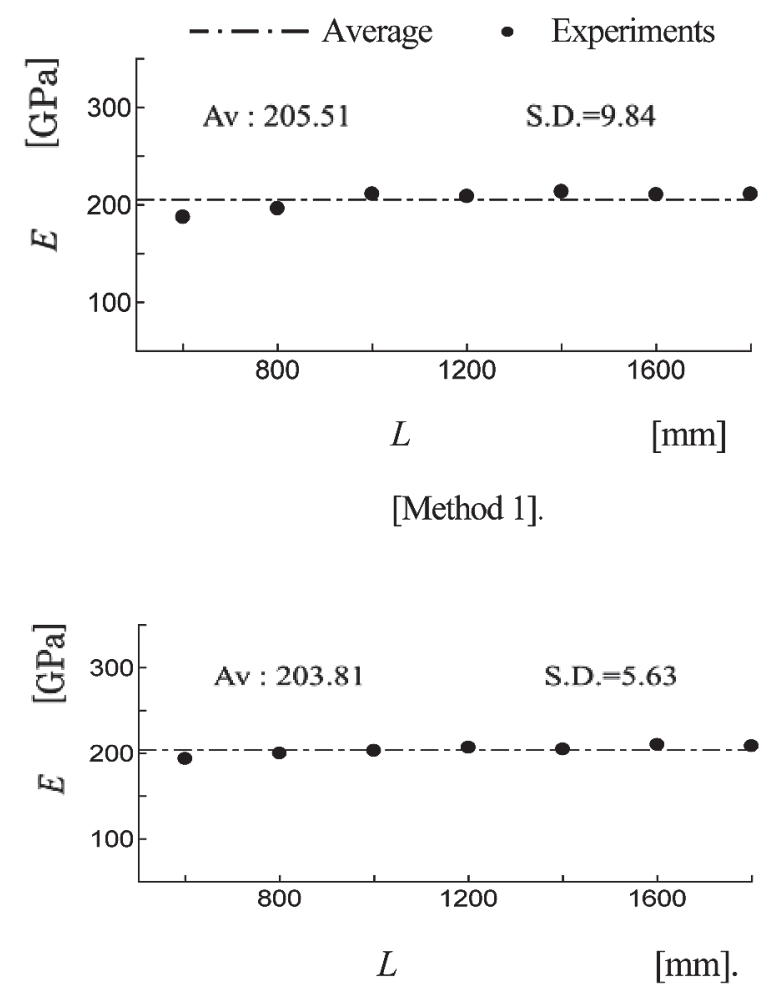

[Method 2].

Fig. 8 Comparison of Young's moduli for an electrdeposited material (Ni: $\left.E_{2}\right)$ between the two measuring methods for various values of the length $L$. (Note: $E_{1}$ of SWP-B is known previously.).

ヤング率が得られることがわかる。したがって，積層円リ ング細線のヤング率測定に際しては基礎データとして最大 水平距離 $x_{\text {max }}$ (測定法 1 ), 最大垂直距離 $y_{\text {max }}$ (測定法 2 )いず れのデータを収集しても両測定法に遜色がない妥当な結果 が得られることから，実験に当たっては適宜いずれか一方 の測定法を採用することも可能であるといえる.

以上の測定例から，新しく開発した自重大変形積層円リ ング法は大仰な装置, 高価な装置を必要しない極めて簡素 な方法を用いて積層各層のヤング率を測定することがで き, しかも簡便な計算図表を活用すれば容易に可撓性材料, 特に曲りクセがついているような積層材料のヤング率算定 には極めて有効で有力な $1 つ の$ 測定法であると推察される. もちろん, 単層の可撓性材料のヤング率算定に応用できる ことはいうまでもないことである,

\section{5 むすび}

微小変形線形理論に基づく従来の一般的なヤング率測定 法(主に，引張試験あるいは圧縮試験，片持ちはり試験， 三点 /四点曲げ試験などを利用)には円リングを利用した 測定法はとんと見かけないし，利用できるのは十分な剛性 を有する単体の弾性体に対するヤング率測定が中心であ る。すなわち，本論文で取り扱った円リング法，しかも自 
重変形を利用した円リング法自体は極めて特異な測定法で あるうえ, 曲りクセのついた可撓性の単体材料ばかりか薄 肉積層材料にも適用可能など, 全く特筆すべき, ユニーク なヤング率測定法なのである。こうした極めて画期的なヤ ング率測定の取り組みについて，ここで明らかになった内 容を要約すると以下の通りである。

（1）上部一端が支持された薄肉積層円リング材料について 自重大たわみ変形を利用した新ヤング率測定法(自重 大変形積層円リング法)を開発した。

(2) 解析理論を基に作成した計算図表(ノモグラフ)を利用 する簡便な手法を提案した。

( 3 ) 測定法の習熟性, 利用の便を考慮し, 積層各層のヤン グ率算出プロセスをわかりやすく例示した.

(4) ヤング率算出の基礎データは, 自重積層円リングの最 大水平距離あるいは最大垂直距離である.

( 5 ) 新測定法の有効性を確かめるため, 測定の難しいめっ き薄膜のヤング率測定に適用した。

( 6 ) ニッケル $(\mathrm{Ni})$ めっきの施されたピアノ細線 $(\mathrm{SWP}-\mathrm{B})$ を用いて，円リングの種々の円周長さ(いわゆる，円 リングの直径の大きさ)に対する測定值への影響を検 討するため積層各層のヤング率測定実験を行った。

(7) 測定結果として, ニッケルめっき積層細線 (SWP-B + $\mathrm{Ni}$ )の計測ヤング率は収集する基礎デー夕(最大水平 距離あるいは最大垂直距離などの変位データ)による 影響はほとんどなく, 水平, 垂直いずれの変位デー夕 を採用してもよい.

( 8 ) 円リングにおける円周長さ／線径比の大きな範囲で は, 測定法 1 (最大水平距離xmax計測法) と測定法 2 (最 大垂直距離ymax計測法)，いずれの方法でもほぼ一定 のヤング率が計測できる。因みに本実験の円周長さ／ 線径比の範囲はおおよそ1200～3600倍程度であった。

(9) 新測定法は, 状況に応じて, 真直薄肉積層材料を円形 状のリングに整形することによってその積層材料を構 成する各層のヤング率を測定することができる(例え ば, 細長い真直薄肉積層材料を小さな長さに切断する ことなく，長いまま測定に供したい場合などに有効）。

(10)装置的に簡素な新測定法の大きな利点は, 積層過程あ るいは保管状態の関係で初期曲率を有することになっ た薄肉積層材料や曲りクセのついた薄肉積層材料など をあえて真直にすることなく円リングに保ったまま構 成各層のヤング率を測定することができることであ る.

(11) 新測定法は, 試験材料の保持が簡単なので, 測定の難 しいカーボンファイバー, オプティカルファイバー, 紙，織布などの非金属薄肉材料の単体としてのヤング 率測定にも適用可能と思われる.

(12) 新測定法は, めっき薄膜をはじめ, 将来的には, 各種 薄膜積層材料(コーティング薄膜, ICチップ上の薄膜, 医用デバイス薄膜, MEMS用薄膜などのマイクロマ テリアルやPVD薄膜, CVD薄膜, クラッド材, ラミネー
ト材など)のヤング率測定へ拡張できる可能性がある. すなわち, 薄板・薄膜自体のヤング率を知りたいだけ ならヤング率既知の薄肉材料 (母材) にヤング率未知の 薄板・薄膜加工処理を施して2層積層材料としたうえ で，2層状態の大たわみ変形実験(1ステップのみの実 験で十分ということ)を行えば目的とする薄板・薄膜 の未知ヤング率を容易に算定することができるのであ る.

【注】：計算図表からの無次元分布荷重 $\gamma$ の読取りに際し, 本図Fig.4，Fig.5を拡大複写して用いれば，所期の目的は ある程度達せられる。もし，上記の拡大複写図より高い精 度を要する場合は，計算図表Fig.4, Fig.5に対応した理論 計算の元データおよびその詳細描画図(本論文末に記載の 補足図, Fig.AおよびFig.B参照)を利用するとよい.

\section{参考文献}

1) Johansson,S., Ericson,F. and Schweitz,J-Ake., J.Appl. Phys., 65, (1989), 122-128.

2）尾田十八, 山田耕二, 坂本次郎, 久保田隆司, 日本機 械学会論文集 (A編)，57-535，(1991）, 686-691.

3）福士みゆき, 宮田寛, 村上明, 日本機械学会論文集 (A 編), 72-718, (2006), 880-885.

4）大槻敦巳, 名城大学理工学部研究報告, No.41, (2001), $18-25$.

5) Ohtsuki, A., Advances in Experimental Mechanics, Vol. IV, (2005), 53 -58.

6) Ohtsuki, A.,Bull. Res. Inst.Meijo Univ., (2005), 101-105.

7) Ohtsuki, A. and Hattori,M.,Experimental Techniques, Vol. II , (1999), 517-522.

8) 大㭇敦巳, 服部将文, 名城大学理工学部研究報告, No.40, (2000), 11-19.

9) Ohtsuki, A., Proc. SEM Annual Conference, (2002), \#74-1 - \#74-4.

10) Ohtsuki, A.,Thin-walled Structures, (2004), 233-244

11）大槻敦巳, 高田 仁, 名城大学総合研究所紀要, No.9 (2004), 1- 6 .

12）薄板 ·細線の弾性特性研究委員会報告（大槻ほか $14 ）$, ばね論文集，No.51，(2006), 63-71.

13) Ohtsuki, A., Proc. SEM Annual Conference, (2006), \#78-1- \#78-4.

14）大槻敦巳，日本ばね学会会報，No.445，(2008）, 4-5.

15）大槻敦巳，日本ばね学会会報，No.455，(2009）, 7-8.

16）大梘敦巳，日本ばね学会会報，No.457，(2009）, 6-7.

17）大槻敦巳，高田仁，ばね論文集，No.47，(2002）, 2731.

18) Ohtsuki, A., Advances in Experimental Mechanics, (2004), 597- 598.

19) Ohtsuki, A., Experimental Mechanics, (2004), \#150-1 \#150-8. 
20) Ohtsuki, A., Proc. SEM Annual Conference, (2005), \# 113-1 - \#113-4.

21）大槻敦巳，鈴木理智，ばね論文集，No.55，(2010)，3944.

22) Ohtsuki, A., Applied Mechanics and Materials, (2010), $371-377$.

23）大梘敦巳，蒋驍，ばね論文集，No. 60，(2015), 15-22.

24) Ohtsuki, A., Advances in Experimental Mechanics VII, Vol.24-25, (2010), 371-377.

25) Ohtsuki, A., Materials Today, Vol.3, (2017), 5915-5920.

26) Ohtsuki, A., Advances in Experimental Mechanics, (2007), 195 - 200.

27) Ohtsuki, A.,Thin-walled Structures, (2008), 189 -196

28）大梘敦巳，林 克典，ばね論文集，No.54，(2009）, 4148.

29) Ohtsuki, A., Exp.Anal. Nano .Eng. Mater.Struct., (2007), 441- 442 .

30) Ohtsuki, A., Proc.13th Inter.Conf.Exp.Mech., (2007), \#2T25-1 - \#2T25-8.

31) Ohtsuki, A., Procedia Engineering., (2011), 1041-1046.

32）大梘敦巳，林 克典，ばね論文集，No.58，(2013）, 2531.

33) Ohtsuki, A., Proc. SEM Annual Conference, (2013), \#97-1 - \#97-7.

34) Ohtsuki, A.,Thin-walled Structures, (2012), 29 -30

35) Ohtsuki, A.,Experimental Mechanics, (2011), 739 -746

36) Ohtsuki, A., Proc.15th Inter. Conf. Exp. Mech., (2012), \#2642-1 - \#2642-10.

37）大槻敦巳，鈴木理智，ばね論文集，No.56，(2011）, 2531.

38) Ohtsuki,A., Proc. 30th DAS Symposium, (2013), \#1131 - \#113-4.

39) Ohtsuki,A., the 20th International Conference on Composite Materials (ICCM 20), (2015), \#3120-2-1\#3120-2-11.

40) Love. A. E. H., "A Treatise on Mathematical Theory of Elasticity”, 4 th ed., Chapter 19, (1944), Dover., New
York.

41) Frisch-Fay. R., "Flexible Bars", (1962), Butterworth., London.

42) Timoshenko, S. P. \& Gere, J. M., "Theory of Elastic Stability", (1961), McGRAW-HILL.

43）土肥 修，鵜飼隆好，大梘敦巳，日本機械学会論文集， 39-323, (1973), 2020-2031.

44）土肥 修，鵜飼隆好，大㭇敦巳，日本機械学会論文集， 40-329, (1974), 132-139.

45）土肥 修，鵜飼隆好，大梘敦巳，日本機械学会論文集， 40-331, (1974), 617-626.

46) Doi,O., Ukai,T., Ohtsuki,A., Bull.of the JSME, 17-105, (1974), 297-304.

47）土肥 修，鵜飼隆好，大槻敦巳，日本機械学会論文集, 41-341, (1975), 72-86.

48）土肥 修, 大㭇敦巳, 日本機械学会論文集, 41-345, (1975), 1354-1362.

49) Doi,O., Ukai,T., Ohtsuki,A., Bull.of the JSME, 18-123, (1975), 940-952.

50）土肥 修, 大㭇敦巳, 日本機械学会論文集, 42-353, (1976), 84-91.

51) Doi,O., Ohtsuki,A., Bull.of the JSME, 19-127, (1976), 940-952.

52) Doi,O., Ohtsuki,A., Bull.of the JSME, 19-135, (1976), 1019-1024.

53）土肥 修, 大槻敦巳, 日本機械学会論文集, 43-367,(1977), 838-850.

54）土肥 修, 大㭇敦巳, 日本機械学会論文集, 43-375 (1977), 4011-4018.

55) Doi,O., Ohtsuki,A., Bull.of the JSME, 20-149, (1977), 1367-1374.

56) Doi,O., Ohtsuki,A., Bull.of the JSME, 21-157 (1978), 1071-1076.

57）土肥 修，大槻敦巳，機械の研究，39-2，(1987), 312318. 


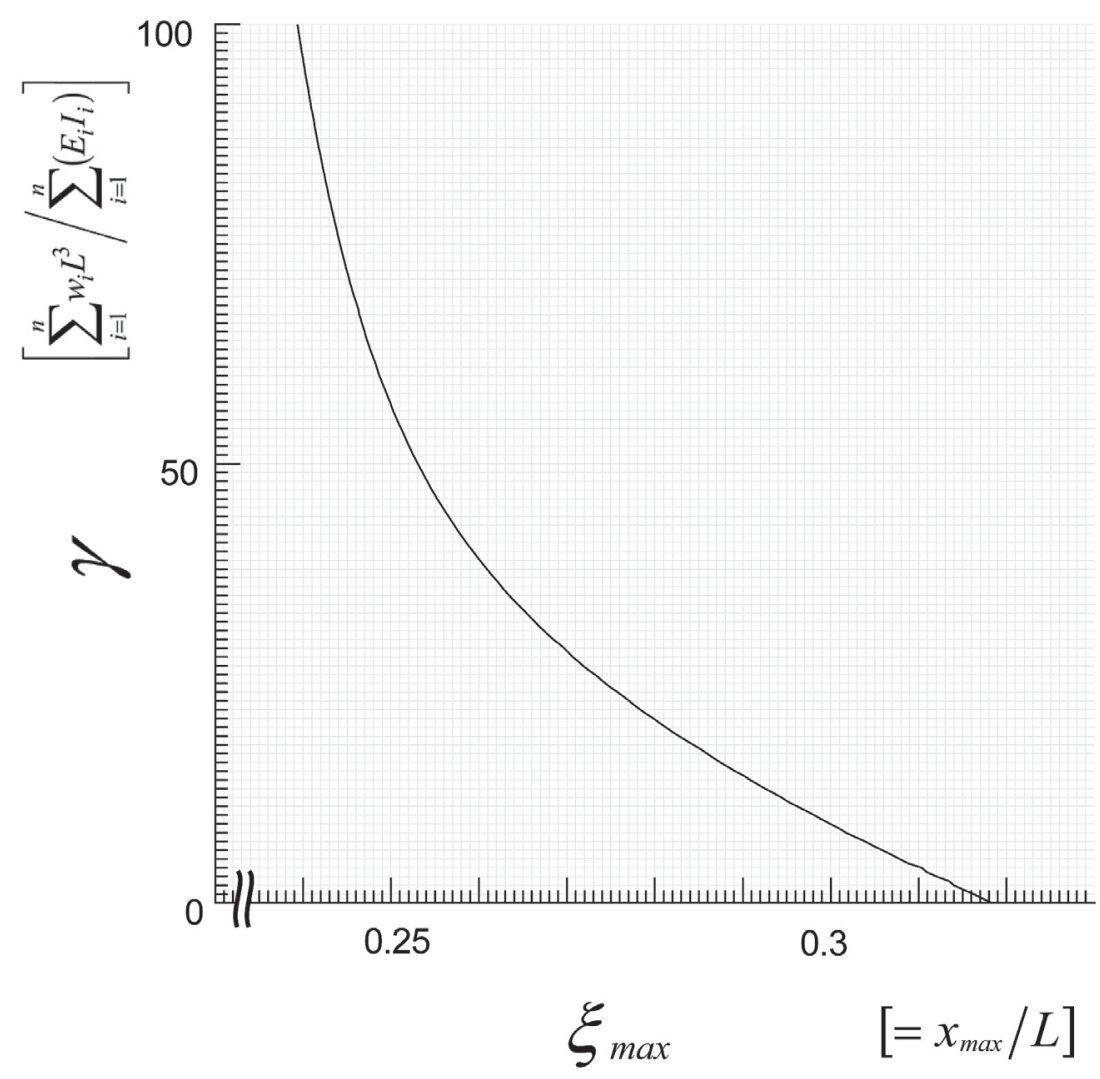

[Appendix: Method 1]

Fig.A Non-dimensional chart for finding the parameter $\gamma$ when the deflection $\xi_{\max }\left(x_{\max } / L\right)$ is given.

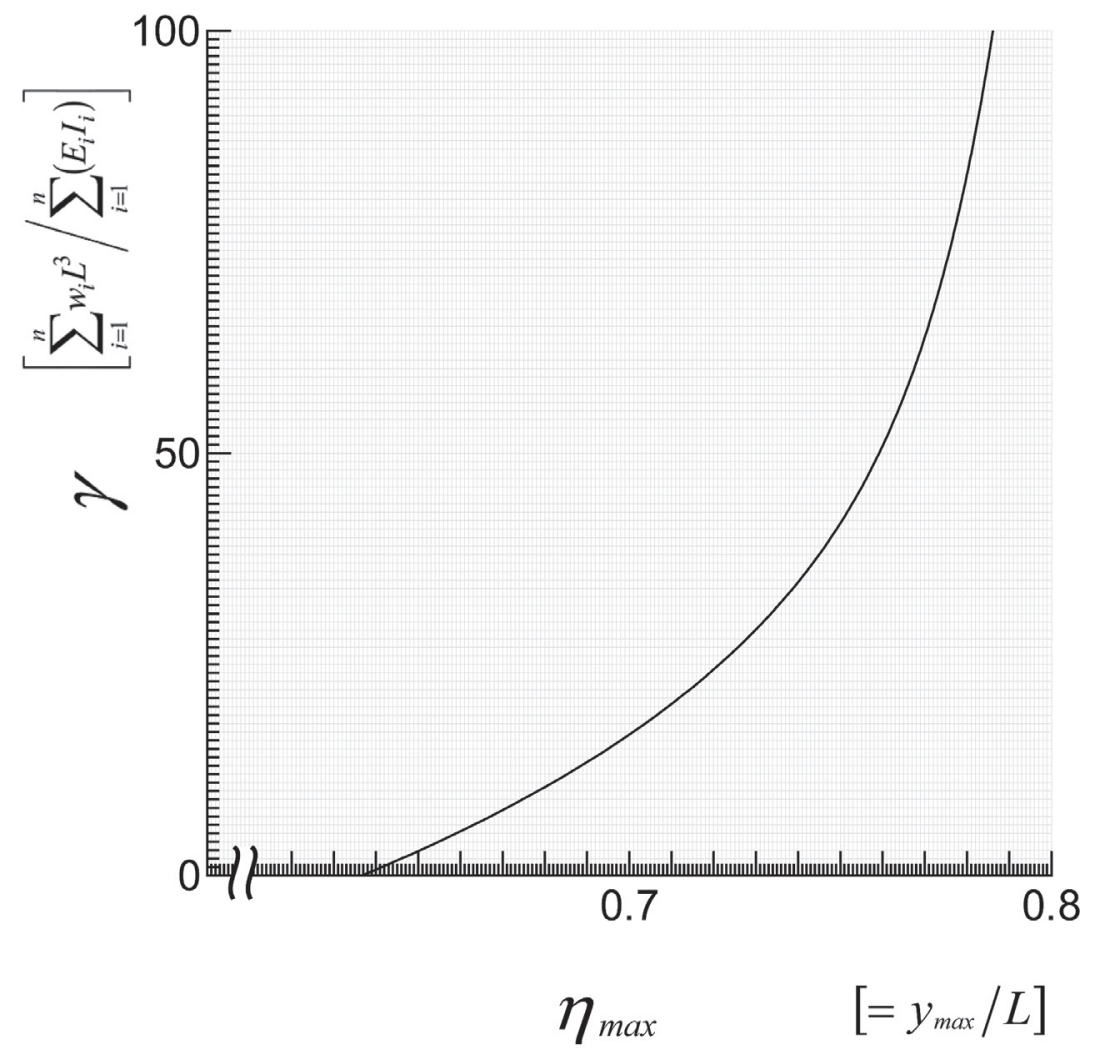

[Appendix: Method 2]

Fig.B Non-dimensional chart for finding the parameter $\gamma$ when the deflection $\eta_{\max }\left(y_{\max } / L\right)$ is given. 